\title{
JOSEPH CONRAD'S HEART OF DARKNESS AS A JOURNEY IN QUEST OF THE SELF
}

\author{
MARÍA ANTONIA ALVAREZ CALLEJA \\ $U N E D$
}

In Conrad's Heart of Darkness, Marlow comes to the Congo for the development of his experience and self, in the belief that a man is shaped by what he does, and that the character is formed by what happens to him. But surrounding all of man's efforts in the Congo there is a presence: Kurtz listened to it and went mad, and Marlow recognizes it but refuses to listen, neutralizes the appeal of the unknown and survives Kurtz, who succumbed to the fascinating wilderness.

In 1899, eleven years earlier than «The Secret Sharer», Conrad published Heart of Darkness, the tale that «delineates the archetypal pattern he continued to refine through his career» (Andreach, 1970:44). In this obscure story Conrad wants to communicate his great conviction that, "even if man fails in his attempts at authenticity, the very struggle to attain it gives intensity to an otherwise plain and inauthentic existence" (Bohlmann, 1991:48). The long-lived popularity of this book over the last one hundred years rest on "its plot of adventure, its humor, and its plain narrative manner -each incidentally averting the audience's attention from racist and misogynist undertones" (Scheick, 1994:45).

Heart of Darkness can be seen as a journey, Marlow's mythical journey, in search of the self, to bring back a new truth. Throughout the novel, the main character relates his experiences journeying up the Congo River in quest of another white man, Kurtz. This enigmatic man had been received by the natives as if he were a god, but perhaps because he had gone into the jungle without knowing himself, and unprepared for the ordeal awaiting him, his misconduct takes him beyond the limits of his heart; thus, he is punished with madness and death. On the contrary, Marlow does not transgress his limits and comes back without fully understanding his experience; although the heart of darkness tries to exercise its influence on him too, he is able to restrain himself by recognizing its fascination and its abomination, and by resisting his desire to join those unspeakable rites -Marlow is saved because his aim is self-knowledge, the mystery of existence, which demands a great humility.

The heart of darkness evoked by Conrad is hard to understand, since the story has different levels, and instead of concentrating on the plot, the reader has to observe the effects which the re-creation of the narrative produces on the narrator, Marlow, since «recent criticism has insisted on the story's being about Marlow, rather than Kurtz, regarding 
it as a journey into Marlow's consciousness» (Kirschner, 1968:47). Thus, although Marlow does not want to bother his audience with what happened to him personally, «yet to understand the effect of it on me you ought to know how I got out there, what I saw, how I went up that river to the place where I first met the poor chap» (p.5). For this reason, the main purpose of this paper is to look for the clues which can illustrate those changes produced on Marlow by the events which take place while penetrating into the heart of darkness.

Marlow's story starts with "a kind of frame-narrator's grave, quiet, brooding voice", and this voice commits us, from the beginning, to "the interior resonance of the story" employing the first person, "to move free where he wishes in time, and therefore free to foreshadow his conclusion" (Henricksen, 1992:27). Conrad introduces us into the narrative, stating how his main character had a passion for maps since he was a little boy:

I would look for hours at South America, or Africa, or Australia, and lose myself in all the glories of exploration. At that time there were many blank spaces on the earth... by this time it was not a blank space any more... It had ceased to be a blank space of delightful mystery... It had become a place of darkness. But there was in it one river especially, a mighty big river, that you could see on the map, resembling an immense snake uncoiled, with its head in the sea, its body at rest curving afar (pp.5-6).

Through the whole story, darkness means for Conrad savagery, primitivism, since the contrast between light/dark, related to the civilized/uncivilized dichotomy, has the connotations of good/evil. Also the reference to the river suggests darkness, since it brings the snake image -a Biblical symbol of evil- which makes Eve disobey God and eat the forbidden fruit.

At the opening of the story, while recalling his childhood fascination with blank spaces on maps, Marlow -the teller of the story-within-a-story, who has a perspective at once intriguing and questionable- evokes a feeling of darkness during his explanation of what happened to him "one evening", when he set out to encounter the wilderness. At this moment, we have the prophetic vision of the darkness that Marlow will find in his journey through his experience in the jungle:

But as I stood on this hillside, I foresaw that in the blinding sunshine of that land I would become acquainted with a flabby, pretending, weak-eyed devil of a rapacious and pitiless folly. How insidious he could be, too, I was only to find out several months later and a thousand miles farther. For a moment I stood appalled, as though by a warning (p.13).

In the growing darkness, Marlow is losing the thread of the story. Most importantly, he compares the narrative to a dream, which may be responsible for the kind of discursive distortion that affects the story itself. In this way, "we are made aware of Kurtz's symbolic role through the recurrent dream-imagery, which locates him as a phantom in Marlow's dream" (Geroski, 1978:73): 
It seems to me I am trying to tell you a dream -making a vain attempt, because no relation of a dream can convey the dream-sensation, absurdity, surprise, and bewilderment in a tremor of struggling revolt, that notion of being captured by the incredible which is of the very essence of dreams (p.24).

After warning the reader that the story is a dream, Marlow is free to tell his subjective experience, involving his audience in this drama of darkness which has no solution: «No, it is impossible; it is impossible to convey the life-sensation of any given epoch of one's existence-that which makes its truth, its meaning-its subtle and penetrating essence. It is impossible. We live, as we dream-alone» (p.24). Here the narrator introduces the seeming theme: in this journey in search of Kurtz, nothing is real but only as it appears to Marlow. Thus his confession: «Of course in this you fellows see more than I could then. You see me, whom you know...» (p.24). At this point the darkness is so intense that the listeners can hardly discern one another. However, the frame-narrator, as an ideal reader aware of the mechanism of Marlow's story-telling, does not miss a word of what is being told:

For a long time already he, sitting apart, had been no more to us than a voice. There was not a word from anybody. The others might have been asleep, but I was awake. I listened, I listened on the watch for the sentence, for the word, that would give me the clue to the faint uneasiness inspired by this narrative that seemed to shape itself without human lips in the heavy night air of the river (p.24).

Marlow's perceptions go on relentlessly for the narrator to make the whole story out of them, out of what he sees, hears and understands. In fact, from the beginning of the story we are able to note the effect of his own words on the audience: «And this also,» said Marlow suddenly, «has been one of the dark places of the earth» (p.3). On this occasion he has said something rather odd, and his remark is received with silence, which is even more odd. But then the silence is explained by the narrator as natural, not odd at all, as if nothing unusual had happened; he has simply made a Marlow-like remark, so typical of him as to be literally unremarkable: «His remark did not seem at all surprising. It was just like Marlow. It was accepted in silence. No one took the trouble to grunt even» (p.3).

Most of the times, during the journey through the forest, Marlow is silent, listening. And the effects this world has on him are mainly the abstract feelings that the wilderness raises in his imagination:

There were moments when one's past came back to one, as it will sometimes when you have not a moment to spare to yourself; but it came in the shape of an unrestful and noisy dream, remembered with wonder amongst the overwhelming realities of this strange world of plants, and water and silence. And this stillness of life did not in the least resemble a peace. It was the stillness of an implacable force brooding over an inscrutable intention. It looked at you with a vengeful aspect (p.30).

Marlow is rather excited at the prospect of meeting Kurtz, a character who never gets to be a flesh-and-blood person, but who is the only one who can solve the enigmas of 
this world. Now Marlow is aware of his defences against the wilderness, and his way of fighting against the powerful nature which surrounds him is by keeping his imagination busy: «I had no time. I had to keep guessing at the channel; I had to discern, mostly by inspiration, the signs of hidden banks; I watched for sunken stones... I had to keep a lookout for the signs of dead wood» (p.30). However, he distinguishes between the mere incidents of the surface and their reality, and what should have been only a device -that is, the structure of the narrative- "has become the main agent of the tale's effect", since what Conrad had sought "by extending the tension produced by rhythm, rhetoric and imagery" is achieved in Heart of Darkness "by involving the reader in an intellectual drama without a solution» (Ambrosini, 1991:114). Although all kinds of responses are demanded, every time Marlow asks his audience: «do you understand?», he is himself the one who cannot understand what he is hearing in his imagination; thus his journey through the wilderness searching for Kurtz, who will help him to interpret the silence of the jungle: «Towards the evening of the second day we judged ourselves about eight miles from Kurtz's station. I wanted to push on» (p.35).

The uneasiness the travelers feel on their approach to Kurtz's station is expressed by using other narrative methods: by Conrad introducing the hearing-seeing theme, in order to express the change from silence/stillness into noise/action,

.... cry, a very loud cry, as of infinite desolation, soared slowly in the opaque air. It ceased. A complaining clamor, modulated in savage discords, filled our ears. The sheer unexpectedness of it made my hair stir under my cap. I don't know how it struck the others: to me it seemed as though the mist itself had screamed, so suddenly, and apparently from all sides at once, did this tumultuous and mournful uproar arise (p.37).

William W. Bancroft has affirmed that "hardship produces terrible sufferings in exile, sacrifice and struggles; these excite admiration and pronounce the heroic in those who rise above them, but when there is no moral stress to call forth the fibre of the deeper man, to bring out latent powers of mind and will, the tragedy is supreme!" (1931:46). Marlow's worst moments in Heart of Darkness are when he is compelled to understand that the great adventure of his life, to which he is devoting such a great efforts, is really a business of death. Congo is splendid; like its people it has a wild vitality, an intense energy of movement, but it is marked by darkness and death: "streams of death in life, in the extremity of an impotent despair; the jungle drives white men mad because of its solitude: there is nobody, not a hut, there is only death, the death of many men, the death of ethical behavior, the death of goodness and civility, the death, crucially, of our authority as selves" (Glassman, 1976:198). Thus, Marlow's decision to adventure after authenticity is not easy; he has been told in Brussels that white men find death, go mad, and only will discover a nightmare in Africa, but Europe had already become an oppressing dream:

'...the earth for you is only a standing place-and whether to be like this is your loss or your gain I won't pretend to say. But most of us are neither one or the other. The earth for us is a place to live in, where we must put up with sights, with sounds, with smells, too, by Jove!' (p.45). 
This dream is «the glow, the story» (Hubbard, 1984:67); the rest of the elements of physical discomfort, such as hardship, danger, isolation and death which envelop the story will be explained in a Marlow-like way to his audience, so that they can judge the significance of all these elements for the narrator:

Land in a swamp, march through the woods, and in some inland post feel the savagery, the utter savagery, had closed round him -all that mysterious life of the wilderness that stirs in the forest, in the jungles, in the hearts of wild men. There's no initiation either into such mysteries. He has to live in the midst of the incomprehensible, which is also detestable. And it has a fascination, too, that goes to work upon him. The fascination of the abomination -you know, imagine the growing regrets, the longing to escape, the powerless disgust, the surrender, the hate (p.4).

The whole series of adjectives -incomprehensible, detestable, mysterious, powerlessand nouns -savagery, wilderness, fascination, abomination- anchor the underlying meaning of the story and have an important effect on the reader, as they obscure the interpretation of events. Darkness is the presence that does not allow for the perception of reality of that mysterious life. This presence that surrounds all of man's efforts in the jungle is listened to by Kurtz and he goes mad while Marlow recognizes it but refuses to listen. At this critical point, when Marlow's senses cannot perceive reality, he turns to Kurtz, the only one who can help him. Throughout the journey, different voices have announced the white man as an artist, as an interpreter of life, and Marlow is longing to meet Kurtz, longing for the shade of 'Mr. Kurtz', since -as Francis A. Hubbard remember- «his painting is the first thing about the Congo that has arrested Marlow»; but what surprises him more is that Kurtz had painted «the somber, sinister sketch» when, like himself, he had been «stuck in the Central Station». This makes Marlow feel an affinity with «this prodigy he had earlier dismissed, with this emissary of pity, and science, and progress, and devil knows what else». (1984:214) Kurtz is the only man in whom he can feel interest, and his interest is quickened to passion when he learns that, most appropriately, the International Society for the Suppression of Savage Customs had entrusted him with the making of a report for future guidance. Through Conrad's irony, the reader is informed that, at last, Marlow has created an image of Kurtz that may be the prototype of the man he himself would have liked to be. He thinks that Kurtz can tell him things about himself which he does not know. And so intensely does he feel the possible connection between himself and the man, that he follows him even though he has no clear sense of his behaviour and thinks that "this must have been before his -let us say- nerves, went wrong, and caused him to preside at certain midnight dances ending with unspeakable rites, which -as far as I reluctantly gathered from what I heard at various times- were offered to him -do you understand?- to Mr. Kurtz himself (p.45). In fact, Marlow knows that Kurtz's experience has become a whole horror, but he cannot avoid loving his genuineness, his authenticity:

He won't be forgotten. Whatever he was, he was not common. He had the power to charm or frighten rudimentary souls into an aggravated witch dance in his honor; he could also fill the small souls of the pilgrims with bitter misgivings: he had one devoted 
friend at least, and he had conquered one soul in the world that was neither rudimentary nor tainted with self-seeking (p.46).

But, in spite of how much he may admire him, Marlow accepts that he is «not prepared to affirm the fellow was exactly worth the life we lost in getting to him» (p.46), what means that Marlow is still «European enough to suppose that behavior matters, that what one does has at least something to do with who one is» (Hubbard, 1984:226). When Marlow at last compares himself to Kurtz, he feels nothing strong or worthwhile; this is the difference between himself and Kurtz: he feels he has lived incompletely, while Kurtz, gross and brutal, has broadened the range of human experience. Although he may have done barbarous things, he has sought new experiences of the self, and, despite the indifference of the universe and the insipidity of men, he has felt all the excitement that life can yield. For instanced, when he now thinks of Kurtz's native woman, she appears to him as a wild and gorgeous apparition:

She walked with measured steps, draped in striped and fringed cloths, treading the earth proudly, with a slight jingle and flash of barbarous ornaments. She carried her head high; her hair was done in the shape of a helmet; she had brass leggings to the knee, brass wire gauntlets to the elbow, a crimson spot on her tawny cheek, innumerable necklaces of glass beads on her neck; bizarre things, charms, gifts of witch men, that hung about her, glittered and trembled at every step (p.56).

For Marlow she is savage and superb, wild-eyed and magnificent, and when we compare this splendid woman with Kurtz's European fiancée, we are setting side by side dynamic energy with sterile hypocrisy, life with death. For this reason, according to Cox, "the novel can be interpreted, in a Freudian manner, as a journey into the wilderness of sex, a fantasy shaped by Conrad's own divided impulses", since Kurtz represents "Marlow's shadow self, the secret sharer, and the voyage of exploration is a night journey into the unconscious" (1974:45). Thus, once back in Brussels, Marlow decides that he will be loyal to her sorrow rather than to Kurtz's death, what for Richard Ambrosini means that he uses his memory as «a shield against the superficial sanity of its citizens», and that "the man who has died with a vision of the horror has been left behind in the protected world of ideal truthfulness» (1991:114). His dialogue with Kurtz's Intended illustrates the price Marlow is going to pay for the girl's sanity:

'You knew him well,' she murmured, after a moment of mourning silence.

'Intimacy grows quickly out there,' I said. 'I knew him as well as it is possible for one man to know another,'

'And you admired him,' she said. 'It was impossible to know him and not to admire him. Was it?' (p.69).

Throughout the scene, the ambiguity of language creates an unbearable tension: Marlow uses the uncertainties that language can offer him in order to obscure the whispers 
which are echoing in his head, "He was a remarkable man... It was impossible not to admire him" (p.69), and in this atmosphere, listening to the Intended's words, Marlow asks himself: which Kurtz is more real, the one in his memory or the one perpetuated by this woman's sorrow?:

'You knew him best,' I repeated. And perhaps she did. But with every word spoken the room was growing darker, and only her forehead, smooth and white, remained illumined by the unextinguishable light of belief and love (p.70).

At this moment, as Allan Junter affirms, "Marlow has entered a place of cruel and absurd mysteries not fit for human beings to understand, eventually agreeing to lie for Kurtz, to cover up his crimes". Junter adds that "Marlow has to lie because he cannot agree to shatter the moral world of the Intended", since her world is based on her love for Kurtz, that "shows itself in deepest mourning a year later. Love is prima facie a generous emotion. Her wait for him is self-abnegation, but is there not a hint of dramatic self-indulgence in the scene, in the egoism of having a hopeless cause to believe in?" (1983:53). Marlow feels the world crumbling around him when the Intended asks after Kurtz's last words:

'Repeat them,' she murmured in a heartbroken tone. 'I want -I want -somethingsomething-to-to live with,' she insisted. 'Don't you understand I loved him-I loved himI loved him!', I was forced into saying a downright lie: I pulled myself together and spoke slowly. 'The last word he pronounced was-your name' (p.71).

This last scene, like the rest of Heart of Darkness, is as example of how Conrad's prose is as vague as it is rich, precisely because of "the absence of concretely visualized outlines of tangible features not so much in language itself as in some of the situations and impressions it evokes", and also because "the frame narrator is drawing the reader's attention to the duality of Marlow's story". He warns his readers that "they must not concentrate on Kurtz's account of the events in which he is protagonist", but rather "on the distortions which the re-creation of his subjective experience produces on the narrative." Thus, "the meaning of the episode lies in the traces of how he experienced those events." (Ambrosini, 1991:90) The Marlow who at the end of his narrative admits: «Hadn't he said he wanted only justice? But I couldn't. I could not tell her. It would have been too dark-to dark altogether» (p.71), is an eloquent portrait of a character who has grown out of telling the tale, as it becomes clear that he is attempting something that seemed impossible, i.e, to render the meaning of a dream. For this reason, the narrative -shaped by the contours of a voyage, a pilgrimage- is associated with impotence. And in this continuous progress into darkness, Conrad's use of Marlow allows him to develop a sense of narrative complicity with the story, complemented by the ensuing human involvement:

We have the guilty complicity of an involved observer -and, moreover, an involved narrator who takes care further to involve his listeners/readers. His achievement is based upon a set of ideological perceptions which, linked together artistically, constitute an 
understanding of imperialism as a particular system, a set of connections, influences and determinations. (Hawthorne, 1990:171)

Moreover, since «Marlow's narrative is retrospective», as H. M. Daleski points out, «he does not recount his experiences in the light of a gained knowledge» (1977:52); he does not understand the meaning of his experience at the beginning of his narrative, and for this reason the tale itself becomes an attempt to penetrate its significance -thus the figure of the Buddha at the end of the novel, symbolizes the attempt to achieve a valid conclusion. For twenty years a critical debate has continued concerning the significance of what has been termed «the Buddha tableaux», and «it is not clear why the narrator compares Marlow to the Buddha, since Conrad does not provide enough information to justify it" (Bonney, 1980:7). The fact, as Jean-Aubryis Georges has suggested, is that the writer seems quite incapable of «believing in any kind of thought-form, and his contempt is directed acidly towards a humanity that doesn't know what it wants» (1927,II:121).

Heart of Darkness, the most famous of Conrad's pilgrim's progress for our pessimistic age, ends with the suggestion that truth is unendurable in the context of everyday life, that what one needs in order to maintain the belief in safety and comfort is some sustaining illusion to which one can be faithful. The story closes with the frame-narrator looking over the tranquil waterway of the Thames, which, for Albert J. Guerard, "seemed to lead into the heart of a long, immense darkness" (1979:33), Conrad's longest journey into self.

\section{BIBLIOGRAPHY}

Ambrosini, Richard (1991) Conrad's Fiction as Critical Discourse. Cambridge Univ. Press.

Andreach, Robert J. (1970) The Slain and Resurrected God: Conrad, Ford, and the Christian Myth. New York: New York University Press.

Bancroft, William W. (1931) Joseph Conrad: His Philosophy of Life. Philadelphia: Stratford Co.

Bohlmann, Otto (1991) Conrad's Existentialism. London: Macmillan.

Bonney, William W. (1980) Thorns \& Arabesques: Contexts for Conrad's Fiction. Baltimore \& London: The Johns Hopkins University Press.

ConRad, Joseph (1937) Conrad's Prefaces to his Works (Intr. Edward Garnett). London: J.M. Dent \& Sons Ltd.

1990 (1899) Heart of Darkness. New York: Dover Publications, Inc.

Cox, C.B. (1974) Joseph Conrad: The Modern Imagination. London: J.M. Dent \& Sons Ltd.

DALEski, H.M. (1977) Joseph Conrad: The Way of Dispossession. London: Faber \& Faber.

Geroski, R.A. (1978) Conrad: The Moral World of the Novelist. London: Elek Books Ltd. 
Georges, Jean-Aubry (1927) Joseph Conrad: Life and Letters. Garden City, New York: Doubleday, Page \& Co.

Glassman, Peter J. (1976) Language and Being: Joseph Conrad and the Literature of Personality. New York \& London: Columbia University Press.

Guerard, Albert J. (1979) Conrad the Novelist. Cambridge, Mass: Harvard University Press.

HawthoRn, Jeremy (1990) Joseph Conrad: Narrative Technique and Ideological Commitment. London \& New York: Routledge.

Henricksen, Bruce (1992) Nomadic Voices: Conrad and the Subject of Narrative. Urbana \& Chicago: University of Illinois Press.

HubBard, Francis A. 1984 (1978) Theories of Action in Conrad. Ann Arbor, Michigan: UMI Research Press.

Junter, Allan (1983) Joseph Contrad and the Ethics of Darwinism. London \& Camberra: Crom Helm.

Kirschner, Paul (1968) Conrad: The Psychologist as Artist. Edinburgh: Oliver \& Boyd.

Scheick, William J. (1994) The Ethos of Romance at the Turn of the Century. Austin: University of Texas Press. 